\title{
Mental health of health workers in Brazil after the COVID-19 pandemic: a systematic review study
}

DOI: $10.46981 /$ sfjhv2n4-010

Received in: Oct 1st, 2021

Accepted in: Dec 31th, 2021

\author{
Rosiane Pinheiro Palheta \\ Doutora em Serviço Social \\ Fundação Hospital Adriano Jorge \\ Address: Avenida Carvalho Leal, S/n. Aleixo. Manaus-Am. \\ E-mail: anypinheiro@hotmail.com
}

\begin{abstract}
The work sought, through a systematic review research, to study the production on mental health of health workers in the post covid-19 pandemic. Thus, a review of the narrative was carried out, which is characterized by critical analysis of the bibliographic production of the research topic, considering the period chosen for the study. A total of 987 works were found, 891 were excluded because 96 of which the abstracts were read, 19 were selected for the sample that actually dealt with the mental health of health professionals and only 11 were selected to compose the study because it was about post impacts. pandemic. The results showed that the mental health of health workers has always been a reality due to the precariousness of the system, however, it was aggravated by the health emergency and the sociopolitical and economic context and an ongoing necropolitics in the country.
\end{abstract}

Keywords: mental health, health worker, pandemic.

\section{INTRODUCTION}

Mental illness has been considered by the World Health Organization (WHO) an epidemic, for some a pandemic (Filho and Dunningham, 2019) and According to WHO, Brazil is considered the most anxious country in the world and the fifth most depressed. This is not surprising since Brazil was one of the countries that were most affected by the covid-19 pandemic and the state of Amazonas presented one of the worst pictures, if not, the worst.

In the global estimates on depression and other mental problems published by the WHO of 2017 Brazil appears in first place in the ranking of anxiety with $9.3 \%$ and $5.8 \%$ of depression that is, the second in the world with the highest rate of the disease.

The first phase of the Ministry of Health Survey that gathered information about the mental health of Brazilians during the Covid-19 pandemic revealed that anxiety is the most present disorder in the period. 
As a partial result an anxiety index of $(86.5 \%)$ was identified; a moderate presence of posttraumatic stress disorder (45.5\%); and a low proportion of depression (16\%) in its most severe high form.

All of these issues during the pandemic, which is still ongoing, coupled with day-to-day concerns, uncertainty about the job market, social and family isolation, insomnia, overwork, imminent risk and fear of contamination by the virus, changes in social interactions, anger, fear, and so many others have been gradually increasing since late 2019 when the pandemic took hold in the world. Such symptoms have been playing a key role in the picture of anxiety and depression and overall mental health in the country.

The aim of the article is to present an analysis of the literature production on the topic of mental health of health professionals during the covid-19 pandemic from a systematic review research.

\section{METHODOLOGY}

The study was performed from a systematic review where the databases were searched: LILACS - Latin American and Caribbean Literature in Health Sciences, MEDLINE - International Literature in Health Sciences, Redalyc Red de Revistas Científicas de América Latina y el Caribe, España y Portugal, SciELO - Scientific Electronic Library Online and PAHO - Pan American Health Organization Library Collection, what was produced about the health of health workers during the covid-19 pandemic since the health sector did not stop and health workers and professionals felt strongly the effects of the health emergency, the increasing call and the repercussions of this for their mental health. A narrative literature review was conducted, with the mental health repercussions of groups and populations in the context of the pandemic for the new.

According to the PRISMA recommendation "A systematic review is a review of a clearly formulated question that uses systematic and explicit methods to identify, select, and critically evaluate relevant research, and collect and analyze data from those studies that are included in the review. Statistical methods (meta-analysis) may or may not be used to analyze and summarize the results of the included studies. Meta-analysis refers to the use of statistical techniques in a systematic review to integrate the results of the included studies" (335:2015)-.

Thus, the search was made by the descriptors: mental health, pandemic and health professionals. In this study, we chose to consider the need to map what was being produced regarding mental health in the pandemic of those who did not stop, that performing remote service was not an option, that fears and suffering for the loss of friends, relatives and family members, was not a reason to stop, moment that vacations and rest were canceled. 
Thus, a narrative review was carried out, which is characterized by critical analyses of the bibliographic production on the research topic considering the period chosen for the study. In this study, by choosing the narrative review, we considered the need to map what had been produced so far on the theme of mental health of those who work in health The inclusion criteria were: publications that studied the mental health of health professionals during the pandemic by the new coronavirus COVID-19, works done between 2020 and 2021. As exclusion criteria were: papers that did not include healthcare workers or healthcare professionals and with repercussions not arising from covid-19.

The search was carried out between the months of August and September 2021, and all the publications were accessed, the abstracts were read, and then 19 articles were selected and read in their entirety, from which 11 articles that met all the research criteria were selected to compose the sample of those included in the study. The 11 articles were reread, abstracts were made, tabulated and analyzed in order to answer the guiding question of the study, that is, how was the mental health of health workers after the pandemic of covid;19 in Brazil.

The analysis of the results occurred from the organization and synthesis of the publications in a synoptic table, type of publication, authors, country, sample, objective, and main results. After that, the analysis and interpretation of the data proceeded with the reading of these summaries and the grouping into similar themes, resulting in two axes of analysis: fragilities and vulnerabilities of the work in health; and psychological illness.

\section{RESULTS}

In the databases searched (PAHO; SCIELO, LILACS, MEDLINE AND REDALYC) from the research descriptors, 987 publications were found where 6.5\% in LILACS, 3.7\% MEDLINE, Redalyc 27\%, SciELO -15.3\%; PAHO, $47.5 \%$ as shown in the graph below. Among the types of studies found were trials $10 \%$, empirical studies $36 \%$, reflection studies $27 \%$, and review studies $27 \%$ of the total studies found.

Even with the descriptors, numerous papers on mental health in the pandemic appeared and before reading the abstracts, the theme of the articles was verified. Of these 987 papers, 891 were excluded because they were repeated in the searched databases, leaving 96 of which the abstracts were read. After reading the abstracts, 19 were selected for the sample that in fact dealt with the mental health of health professionals, and only 11 were selected for the study because they dealt specifically with the pandemic and the impacts on the mental health of health workers.

These articles were read in full, summarized, results tabulated and analyzed. The articles found were about mental health $(9 \%)$, mental health of health professionals $(18 \%)$, mental health of health 
workers (18\%), and mental health of nurses (55\%), which was part of 55\% of all research done on the topic. The data are in the table below:

Table 1 - Number of studies selected for sample using the keywords "mental health in the pandemic", "health workers"
\begin{tabular}{|l|c|c|} 
Topic & Total found & $\%$ \\
\hline Mental Health & 1 & 9 \\
$\begin{array}{l}\text { Mental Health Health } \\
\text { Professionals }\end{array}$ & 2 & 18 \\
Mental health nurses & 6 & 55 \\
\hline $\begin{array}{l}\text { Mental Health Health Care } \\
\text { Workers }\end{array}$ & 2 & 18 \\
TOTAL & 11 & 100 \\
\hline
\end{tabular}

Source: Prepared by the author, 2021.

Most of the studies dealt with the impacts of the pandemic on the mental health of nursing professionals. This fact is related to the fact that nurses, technicians, and nursing assistants work directly with inpatient care, that is, they directly suffer the greatest risks for being in the front line of hospital care and high complexity.

Many professionals have had to isolate themselves and stay away from relatives and family members in order to protect themselves and avoid contagion. According to data from the nursing observatory until the beginning of November, there were 58,965 cases of professionals infected by covid-19, with 869 deaths, of which $85.31 \%$ were women. $36 \%$ of the papers aimed to study mental health among health professionals and health workers.

In this sense, the work of Horta Et all, 2021 corroborates these data when it places the predominance of women (81\%) in frontline activity, predominantly technical level (69\%) and nursing area $(76 \%)$ with high weekly workload and average of 51.8 hours per week.

Note that there is a difference between these two professional categories, one who is a worker and the other a health professional and the studies focused on one or the other category, the difference between them basically being that the worker acts in the means and ends of the process contributing to the guarantee of care and the health professional is the one trained in the health area who acts directly in health care but both work in health units whether in basic care, medium or high complexity.

Queiroz et all, 2021 in a study on how nursing professionals interact with the 'new' of the pandemic of the COVID-19 and what are the impacts on mental health ( ), the professionals had to face high levels of fear, uncertainty and insecurity in the performance of care, even for being something new without a proper safety protocol established among other issues. 
In the scope of interaction with the daily work, in the involvement with the 'new', with the institutions, sectors, with the doing and with the work process, the discourse revealed that the Nursing professionals the pre-existing degradations in the profession, of low valuation and precariousness were strongly impacted by new degradations, which overlap and sometimes mischaracterize their doing, as reinforced in the literature. (Queiroz et al, 202108 ).

Pereira ET all, 2020 afirma que os profissionais de saúde, sobretudo os da enfermagem, À medida que são desencorajados a se relacionar de maneira próxima com outros indivíduos, é mais crescente o aumento do sentimento de isolamento, da sensação de vazio dentre outros sentimentos negativos no decurso do tempo e o aprofundamento da pandemia além de muitas vezes o enfermeiro é colocado em situações de emergência que o pressiona a execução de tarefas exaustivas, além de longas e extensas jornadas de trabalho, plantões extenuantes, acompanhado da vivência do óbito e a sensação de incapacidade diante do poder do vírus que acabam por expor a fragilidade e a suscetibilidade ao estresse, Síndrome de Burnout (SB) e os demais sofrimentos psíquicos. O quadro abaixo resumo os achados na pesquisa:

Table 2 - Summary of the papers in the sample

\begin{tabular}{|c|c|c|c|}
\hline Authors & Year & Goals & Type of study \\
\hline Paula Gaudenzi & 2021 & $\begin{array}{l}\text { To point out and reflect on } \\
\text { some effects of the Covid-19 } \\
\text { pandemic on the mental } \\
\text { health of } \\
\text { Brazilians. }\end{array}$ & Assay \\
\hline $\begin{array}{l}\text { Katarina Márcia Rodrigues } \\
\text { dos Santos } \\
\text { Maria Helena Rodrigues } \\
\text { Galvão2 } \\
\text { Sávio Marcelino Gomes } \\
\text { Talita Araujo de Souza } \\
\end{array}$ & 2021 & $\begin{array}{l}\text { To analyze the prevalence } \\
\text { of depression and anxiety } \\
\text { symptoms and associated } \\
\text { factors in professional } \\
\text { nursing staff during the } \\
\text { Covid-19 pandemic. }\end{array}$ & Empirical \\
\hline $\begin{array}{l}\text { Arthur de Almeida } \\
\text { Medeiros } \\
\text { Isabelle Ribeiro Barbosa }\end{array}$ & & & \\
\hline $\begin{array}{l}\text { Maria de Lourdes } \\
\text { Custódio Duarte, Daniela } \\
\text { Giotti da Silva, Mariana } \\
\text { Mattia Correa Bagatini }\end{array}$ & 2021 & $\begin{array}{l}\text { Reflecting on the mental } \\
\text { health of nursing } \\
\text { professionals in the context } \\
\text { in the } \\
\text { coronavirus pandemic. }\end{array}$ & Reflection \\
\hline $\begin{array}{l}\text { Norma Valéria Dantas de } \\
\text { Oliveira Souza } \\
\text { Eloá Carneiro Carvalho } \\
\text { Samira Silva Santos } \\
\text { Soares } \\
\text { Thereza Christina Mó Y } \\
\text { Mó Loureiro Varella } \\
\text { Sandra Regina Maciqueira } \\
\text { Pereira } \\
\text { Karla Biancha Silva de } \\
\text { Andradea }\end{array}$ & 2021 & $\begin{array}{l}\text { To reflect on the work } \\
\text { context of nursing } \\
\text { professionals in the Covid- } \\
19 \text { pandemic and the } \\
\text { repercussions for } \\
\text { mental health of these } \\
\text { professionals. }\end{array}$ & Reflection \\
\hline $\begin{array}{l}\text { Rogério Lessa Horta } \\
\text { Eduardo Guimarães } \\
\text { Camargo } \\
\text { Marcus Levi Lopes } \\
\text { Barbosa } \\
\text { Pedro José Sartorelli } \\
\text { Lantin } \\
\text { Talia Greici Sette } \\
\text { Thaís Caroline Guedes } \\
\text { Lucini } \\
\text { Aline Faria Silveira } \\
\text { Lizziê Zanini } \\
\text { Bibiana Andrade Lutzky }\end{array}$ & 2021 & $\begin{array}{l}\text { Investigate the effects of } \\
\text { frontline COVID-19 } \\
\text { performance on the mental } \\
\text { health of public hospital } \\
\text { professionals. }\end{array}$ & Empirical \\
\hline
\end{tabular}




\begin{tabular}{|c|c|c|c|}
\hline $\begin{array}{l}\text { Pollyanna Canuto, Kalyne } \\
\text { Bezerra, Hevillyn } \\
\text { Barbosa2, \& Luana Lima }\end{array}$ & 2020 & $\begin{array}{l}\text { Evaluate the effects of } \\
\text { COVID-19 on the } \\
\text { psychological state of health } \\
\text { care workers and actions to } \\
\text { reduce } \\
\text { of this damage. }\end{array}$ & Review \\
\hline $\begin{array}{l}\text { Aline Macêdo Queiroz } \\
\text { Anderson Reis de Sousa } \\
\text { Wanderson Carneiro } \\
\text { Moreira } \\
\text { Maria do Perpétuo } \\
\text { Socorro Sousa Nóbrega } \\
\text { Milena Bitencourt Santos } \\
\text { Laura Jennifer Honorato } \\
\text { Barbossa } \\
\text { Larissa de Almeida Rezio } \\
\text { Sonia Regina Zerbetto } \\
\text { Priscila Maria Marcheti } \\
\text { Cintia Nasi } \\
\text { Elda de Oliveira }\end{array}$ & 2021 & $\begin{array}{l}\text { To understand the impacts } \\
\text { on the mental health of } \\
\text { nursing professionals when } \\
\text { faced with interactions with } \\
\text { the } \\
\text { new' from the Covid-19 } \\
\text { pandemic. }\end{array}$ & Empirical \\
\hline $\begin{array}{l}\text { Aline Marcelino Ramos- } \\
\text { Toescher } \\
\text { Jamila Geri } \\
\text { Tomaschewisk-Barlem } \\
\text { Edison Luiz Devos Barlem } \\
\text { Janaina Sena Castanheira }\end{array}$ & 2020 & $\begin{array}{l}\text { Reflect on the implications } \\
\text { of the coronavirus pandemic } \\
\text { on the mental health of } \\
\text { nursing professionals and } \\
\text { the key support resources } \\
\text { being developed. }\end{array}$ & Reflection \\
\hline \multicolumn{4}{|l|}{ Rodrigo Liscano Toescher } \\
\hline $\begin{array}{l}\text { Mara Dantas Pereira } \\
\text { Erivelton Cunha Torres } \\
\text { Miria Dantas Pereira } \\
\text { Paola Fernanda Santos } \\
\text { Antunes } \\
\text { Cleberson Franclin } \\
\text { Tavares Costa }\end{array}$ & 2020 & $\begin{array}{l}\text { Perform a reflection } \\
\text { a theoretical theory about } \\
\text { the emotional distress of } \\
\text { nurses in the hospital } \\
\text { context in the face of the } \\
\text { COVID-19 pandemic. }\end{array}$ & Review \\
\hline $\begin{array}{l}\text { Eduardo Bassani } \\
\text { Dal'Bosco } \\
\text { Lara Simone Messias } \\
\text { Floriano } \\
\text { Suellen Vienscoski } \\
\text { Skupien } \\
\text { Guilherme ArcaroI } \\
\text { Alessandra Rodrigues } \\
\text { Martins } \\
\text { Aline Cristina Correa } \\
\text { Anselmo }\end{array}$ & 2020 & $\begin{array}{l}\text { Identify the prevalence and } \\
\text { factors associated with } \\
\text { anxiety and depression in } \\
\text { professionals } \\
\text { of nurses who work with } \\
\text { COVID-19 in a university } \\
\text { hospital. }\end{array}$ & Empirical \\
\hline $\begin{array}{l}\text { Fernanda Berchelli Girão } \\
\text { Miranda } \\
\text { Mellina Yamamura } \\
\text { Sarah Salvador Pereira } \\
\text { Caroline dos Santos } \\
\text { Pereira } \\
\text { Simone Teresinha Protti- } \\
\text { Zanatta1 } \\
\text { Marceli Karina Costa } \\
\text { Sonia Regina Zerbetto } \\
\end{array}$ & 2021 & $\begin{array}{l}\text { To systematically map the } \\
\text { knowledge production, with } \\
\text { national and international } \\
\text { literature, of situations of } \\
\text { psychological distress that } \\
\text { nursing professionals } \\
\text { experience when exposed to } \\
\text { the pandemic of COVID-19. }\end{array}$ & Review \\
\hline
\end{tabular}

Source: Prepared by the author, 2021

The studies reflect on the implications of the pandemic coronavirus on the mental health of nursing professionals and other health professionals, reflect theoretically on the emotional suffering in the hospital context facing the pandemic of COVID-19, identify the prevalence and factors associated with anxiety and depression, and mental health in general, in addition to systematically mapping the 
production of knowledge, with the national and international literature on the psychological suffering of these professionals.

In the study by Dal'Bosco Et all, 2020, the prevalence of anxiety in nursing professionals was $48.9 \%$ and of depression was $25 \%$ who were also mostly women working 40 hours a week. "a large proportion of patients affected by COVID-19 present severe symptoms, especially respiratory syndromes, requiring intensive care, which justifies a higher prevalence of anxiety in workers in critical sectors." (Dal'Bosco Et all, 2020: 05).

Paula Gaudenzi, 2021,calls attention to the Social inequalities in the Brazilian reality and presents scenarios of Mental Health in Covid-19 times. The author puts the blunt criticism that draws the scenario of "generalized fear" as a complex and contradictory reality, in which few leave their cities in jets equipped with ICU, while many get contaminated in the lines of the Caixa Economica in search of the emergency "aid" offered by the federal government and many others die for lack of respirators in public hospitals, a cruel show of the "unequal redistribution of vulnerability".

\section{DISCUSSION}

The pandemic changed the daily life of health professionals, posing challenges for which they were not prepared. Moreover, the historical, cultural, and economic context in course in the country contributed to deepen the problems and to trigger the illness of the categories that perform activities in the health area, especially those who work in the front line.

In this sense, studies have shown that mental illness and psychological suffering are rooted in social inequalities (Gaudenzi, 2021; Santos et all 2021) deepened by the social distance from the pandemic (Santos et all, 2021) and neglected by the lack of management, strategy and care for workers (Duarte et all, 2021).

In addition, other studies have shown that factors such as: Long working hours and difficulties with dressing, among other items aggravating stress, especially the nursing professionals (Horta et all, 2021), the circumstantial increase in the demand of services and the shortage of supplies and personnel (Santos et all 2021), the complexity of virulence and the dimension of the "new" virus (Queiroz et all 2021) and the imminent risk of infection by the virus, illness and death; impotence and exhaustion in the face of constant exposure and deaths that cannot be avoided (Pereira et all, 2020) influenced and determined the illness of health professionals and workers in this period.

There are other aspects that also need to be discussed, especially in Brazil, where economic packages were approved freezing salaries in the public area where professionals of the Unified Health System already had a growing salary deficit, which was aggravated with the pandemic, in several states 
and municipalities, the enjoyment of vacations, licenses and leaves of absence were suspended, which further overloaded the workers, raising the level of stress and mental suffering.

It is necessary to emphasize that these workers and health professionals have not had the time and opportunity to prepare themselves for something still unknown, there has been no training for these professionals requiring them to do the work even though they are unaware of the best form of protection and the high risk of contamination, being "thrown to the lions" leading many teams to widespread contamination due to lack of preparation and ignorance of the severity and high mortality of the virus.

The data on deaths of professionals and health workers are estimates, there is no exact number. According to a survey of data from the Brazilian registries, 5,798 male and female workers in the sector have lost their lives since March of last year in Brazil, but these data are accounted for until April of this year (Lacerda, 2021). Other data indicate that around 115,000 health professionals have died victims of COVID-19; for the World Health Organization (WHO), between 80,000 and 180,000 health professionals may have died since the beginning of the pandemic, all over the world.

No plan was heard that brought concern for these professionals, there was no real action at the national, state or municipal level for the protection of workers, on the contrary, there was a lack of PPE's everywhere, and at the beginning of the pandemic, there was a lack of basic materials such as mask, paper towel, ice and liquid alcohol, in addition to contingency of hospital and consumer materials, especially after the Constitutional Amendment 95/2016 that establishes New Fiscal Regime under the Union's Fiscal and Social Security Budgets and individualized limits for primary expenditures. In Art. 109 in the case of non-compliance with the individualized limit, the following prohibitions, among others, apply to the Executive Branch or to the organ listed in items II to V of the caput of art. 107 of this Act of Transitional Constitutional Provisions that did not comply with it, without prejudice to other measures, until the end of the fiscal year when the expenses return to the respective limits: I - concession, at any title, of advantage, increase, adjustment or adjustment of remuneration of members of Power or body, of public and military servers and employees, except those derived from final and unappealable court decision or legal determination arising from acts prior to the entry into force of this Constitutional Amendment; Alteration of career structure that implies increase of expenses; holding of public competition; creation or increase of aids, advantages, bonuses, allowances, representation funds or benefits of any nature, all prohibitions that incur, directly on the valuation of the public servant.

A study on the working conditions of health professionals based on reports published on the Internet by journalistic communication vehicles, found in 15 journalistic reports that health professionals, from different locations in Brazil, faced problems regarding the adequate supply of PPE. In addition, the study pointed out several cases in which male and female workers were removed due to 
suspicion of COVID-19 and, still, had difficulties in performing exams and in treatment and care. (Vedovato et all,2021).

In addition, according to our experience as a healthcare worker, at a certain moment of the pandemic, the safest period of absence of 14 days was reduced to 7, which put many professionals in a situation of uncertainty and insecurity and at risk of virus transmission. The Technical Note n. 04/2020 with guidelines for health services: prevention and control measures that should be adopted during the assistance to suspected or confirmed cases of infection by the new coronavirus (SARS-CoV-2) turned to health assistance from reception to disinfection and patient care, but neglecting all health professionals and caregivers, who were not called to discuss the plans and were not considered essential to the healthdisease process in the context of the pandemic.

Certainly the mental illness of health workers and professionals is due to the fact that they have been alienated from the planning process and the execution of actions, they have only been the extended arm to carry out what was planned, it was not taken into consideration that they are also users of SUS, that they would be exposed to illness and contamination by the virus, that they would also be the main victims and that, being part of the system, they should be a priority since they are the main part of the fight against the pandemic to avoid the total collapse of the system.

It is necessary that the health professionals and workers participate in the process of health production at the macro level, that they are called and prioritized in the execution and management of the policies, that they are managers of their work process and once they are heard and their demands are inserted and taken into consideration, that they are protagonists of the whole process of management, planning, and are not restricted to the mere executor of the actions, that they get out of the role of extra and become protagonists of the larger process of health care.

\section{FINAL CONSIDERATIONS}

The pandemic took everyone by surprise and, at the same time that it put everyone at the same risk, it deepened and made public our social inequalities, and it was no different in the health system. Health professionals lost their lives the most in the fight against the pandemic due to internal and external factors, and to a necropolitical policy that also affected health workers and professionals, especially those on the front lines of the fight against the pandemic, who clearly opted to leave workers to their fate due to the mortality of the virus.

Those who survived, few came out unscathed after what they lived, experienced, and witnessed, I could even say, were accomplices, even unintentionally. Mental illness was only one of the inheritances, and it is still ongoing, because to be affected by witnessing was not enough, many 
witnessed the death of loved ones, co-workers, neighbors, friends, or knew someone who lost someone important.

How not to be affected? It remains to be seen what will happen from now on, what can be done to minimize the damage of the pandemic on mental health and the lives of health care workers. 


\section{REFERENCES}

Gaudenzi P. Cenários brasileiros da Saúde Mental em tempos de Covid-19: uma reflexão. Interface (Botucatu). 2021; 25(Supl. 1).

Santos KMR, Galvão MHR, Gomes SM, Souza TA, Medeiros AA, Barbosa IR. Depressão e ansiedade em profissionais de enfermagem durante a pandemia da covid-19. Esc Anna Nery 25 (spe) 2021.

Duarte MLC, Silva DG, Bagatini MMC. Enfermagem e saúde mental: uma reflexão em meio à pandemia de coronavírus. Rev Gaúcha Enferm. 2021.

Brasil, Presidência da República, Emenda Constitucional 95/2016.

Souza NVDO, Carvalho EC, Soares SSS, Varella TCMML, Pereira SRM, Andrade KBS. Trabalho de enfermagem na pandemia da Covid-19 e repercussões para a saúde mental dos trabalhadores. Rev Gaúcha Enferm. 2021.

Horta, RL, Camargo, EG, Barbosa, MLL, Lantin, PJS, Sette, PG, Guedes, Lucini, TCG, Silveira, AF, Lutzky, LZBA. O estresse e a saúde mental de profissionais da linha de frente da COVID-19 em hospital geral. Jornal.Brasileiro Psiquiatria. 2021.

Canuto, P, Bezerra, K, Barbosa, H, Lima, L. Covid-19 e o psicológico dos trabalhadores de saúde: uma epidemia oculta. Psicologia, saúde \& doenças, 2020, 21(3), 661-675.

Lacerda, 2021. Brasil já perdeu quase 6 mil profissionais de saúde durante a pandemia do coronavírus, Brasil de fato: Uma visão popular do Brasil e do mundo. São Paulo (SP). 06 de Abril de 2021. Disponível em: https://www.brasildefato.com.br/2021/04/06/brasil-ja-perdeu-quase-6-mil-profissionais-de-saudedurante-a-pandemia-do-coronavirus

Queiroz AM, Sousa AR, Moreira WC, Nóbrega MP, Santos MB, Barbossa LJ, et al. O 'NOVO’ da COVID-19: impactos na saúde mental de profissionais de enfermagem?. Acta Paul Enferm. 2021;34:eAPE02523.

Ramos-Toescher AM, Tomaschewisk-Barlem JG, Barlem ELD, Castanheira JS, Toescher RL. Saúde mental de profissionais de enfermagem durante a pandemia de COVID-19: recursos de apoio. Esc Anna Nery 2020;24(spe):e20200276.

Mara Dantas Pereira, MD, Torres, EC, Pereira, MD, Antunes, PSF, Costa, CFT. Sofrimento emocional dos Enfermeiros no contexto hospitalar frente à pandemia de COVID-19. Research, Society and Development, v. 9, n. 8, e67985121, 2020.

Dal'Bosco EB, Floriano LSM, Skupien SV, Arcaro G, Martins AR, Anselmo ACC. Mental A saúde mental da enfermagem no enfrentamento da COVID-19 em um hospital universitário regional. Rev Bras Enferm. 2020;73(Suppl 2):e20200434.

Miranda FBG, Yamamura M, Pereira SS, Pereira CS, Protti-Zanatta ST, Costa MK, Zerbetto SR. Sofrimento psíquico entre os profissionais de enfermagem durante a pandemia da COVID-19: Scoping Review. Escola Anna Nery 25(spe)2021. 
Vedovato, TG, Andrade, CB, Daniela Lacerda Santos, DL, Bitencourt, SM, Almeida, LP, Sampaio, JFS. Trabalhadores (as) da saúde e a COVID-19: condições de trabalho à deriva?. Rev. bras. saúde ocup. 46, 2021. 